\title{
Optic neuritis due to immunobiologics: first Brazilian case report ${ }^{*}$
}

\author{
Neurite óptica por imunobiológico: relato do primeiro caso brasileiro
}

\author{
Luiz Gustavo Martins da Silva ${ }^{1}$ \\ Carlos José Nelli ${ }^{3}$ \\ Marilda Aparecida Milanez Morgado de Abreu ${ }^{5}$
}

\author{
Letícia Soares Sasso ${ }^{2}$ \\ Fred Bernardes Filho ${ }^{4}$
}

\begin{abstract}
The change in immunological response obtained by immunobiologics has brought a new paradigm to the treatment of immune-mediated disorders. As a result of their efficacy, there is a positive impact on the quality of life of patients. However, severe side effects, such as demyelination of cerebral or peripheral nerves, have been reported. After review of literature using PubMed and MEDLINE data from 2000 to 2012, we identified the cases correlating the biological uniterms and optic neuritis. This article reports the first Brazilian optic neuritis case associated with the use of immunobiologics. This publication is justified by the rarity of the disease and atypical therapeutical evolution.
\end{abstract}

Keywords: Optic neuritis; Psoriasis; Tumor necrosis factor-alpha

Resumo: A mudança da resposta imunológica, obtida pelos imunobiológicos, trouxe um novo paradigma no tratamento das doenças imuno-mediadas. Pela sua eficácia, trazem impacto positivo na qualidade de vida dos pacientes. Entretanto, efeitos colaterais graves, como desmielinização cerebral ou nos nervos periféricos, foram relatados. Após revisão da literatura usando o banco de dados do PubMed e da MEDLINE de 2000 a 2012, identificamos os casos correlacionando os unitermos biológicos e neurite óptica. Este artigo relata o primeiro caso brasileiro de neurite óptica associado ao uso de imunobiológico. Justifica-se esta publicação pela raridade e pela evolução terapêutica atípica.

Palavras-chave: Fator de necrose tumoral alfa; Neurite óptica; Psoríase

\section{INTRODUCTION}

Psoriasis is a chronic inflammatory disease of the skin and articulations, immunologically mediated, with a genetic basis and great polymorphism with clinical expression. ${ }^{1,2}$ Of universal occurrence, it affects men and women equally. Around $25 \%$ of all patients require systemic treatment. ${ }^{2,3}$ Among the options for systemic treatment, there is the immunobiologics group. These are indicated in case of moderate to severe psoriasis that is recalcitrant, when there is con- traindication, intolerance or failure of classical systemic therapy, as well as in patients with severe quality of life deterioration. These medications of protein rich nature interfere in an infrequent and specific way with the immune system. They are extremely potent in the treatment of psoriasis and other inflammatory diseases. However, its long-term effect remains unknown. Adverse effects, such as reactivation of infectious diseases (like tuberculosis), development of anti-DNA

Received on 19.11.2012.

Approved by the Advisory Board and accepted for publication on 18.03.2013.

* Work performed at Presidente Prudente Regional Hospital - Universidade do Oeste Paulista (HRPP-UNOESTE) - Presidente Prudente (SP), Brazil.

Conflict of interest: None

Financial funding: None

MD, Specialist in Dermatology - Dermatology Service - Presidente Prudente Regional Hospital - Universidade do Oeste Paulista (HRPP-UNOESTE) Presidente Prudente (SP), Brazil.

MD, Specialist in Ophthalmology - Ophthalmology Service - Presidente Prudente Regional Hospital - Universidade do Oeste Paulista (HRPP-UNOESTE) Presidente Prudente (SP), Brazil.

MD, Assistant Professor, Dermatology Service - Presidente Prudente Regional Hospital Universidade do Oeste Paulista (HRPP-UNOESTE) - Presidente Prudente (SP), Brazil.

MD, Graduate student, Professor Rubem David Azulay Institute of Dermatology of Rio de Janeiro Santa Casa da Misericórdia Hospital (IDPRDA - SCMRJ) Rio de Janeiro (RJ), Brazil.

MD, Head of Dermatology Service at the Presidente Prudente Regional Hospital - Universidade do Oeste Paulista (HRPP-UNOESTE) - Presidente Prudente (SP), Brazil.

(C)2013 by Anais Brasileiros de Dermatologia 
antibodies and lupus-like syndromes, hematological alterations, congestive cardiac insufficiency and demyelinating diseases have been described. The impact of these side effects on treatment feasibility has not been completely established yet. ${ }^{1,2,3}$

The objective of this study is to report the case of a patient with extensive psoriasis vulgaris who, upon receiving treatment with infliximab, developed optic neuritis and worsening of sight in the affected eye, with no improvement after 3 years of follow-up. This is the first Brazilian case of optic neuritis associated with the use of immunobiologics.

\section{CASE REPORT}

A female, 62-year-old patient, white, widow, retired housekeeper, originally from Presidente Prudente - SP was under treatment for psoriasis vulgaris in plaques, which had started 9 years ago. She was hypertensive, a condition controlled with the daily use of captopril. She used low potency corticosteroids and topic moisturizers, acitretin and methotrexate orally, but there was no response to these treatments. The use of immunobiologics was subsequentely prescribed. No Psoriasis Area and Severity Index (PASI) or the Life Quality Index reports were available. Previous routine exams (PPD, chest radiography, complete blood count, biochemical profile and liver enzymes) did not show alterations. Live virus vaccination was not advised. Three intravenous infusions of diluted infliximab, at $5 \mathrm{mg} / \mathrm{kg}$, were applied in 3 hours and repeated 2 and 6 weeks later. Three days after the third infusion, the patient presented low visual acuity in the left eye, which required an emergency appointment with an ophthalmologist of a private clinic in the city of Presidente Prudente. At the clinical examination, lowering of visual acuity (counting of fingers at 3 meters) and blurring of peripheral region of the optic disc were noticed during fundoscopy. Optic neuritis was then hypothesized and she was submitted to retinography. The findings confirmed the proposed hypothesis (Figure 1). The patient was referred to the emergency ophthalmologic center at the Regional Hospital of Presidente Prudente - SP, where the same findings were confirmed. Immediate hospitalization was decided and pulse therapy started with intravenous methylprednisolone, without previous prescription of oral corticosteroids. Head tomography was done to rule out other causes, such as tumors and cerebrovascular accident, with normal results (Figure 2). To better evaluate the optic nerve and exclude other sources of demyelination (common in multiple sclerosis cases), a head MRI was performed, which found a hypersignal of the left optic nerve in comparison with the right optic nerve in $\mathrm{T} 2$. This supported the diagnostic hypothesis of optic neuritis in the left eye (Figure 3). To objectively translate the sight alterations felt by the patient, a visual campimetry was performed, which showed a normal visual field for the right eye and alterations in the left eye: dense cecocentral absolute scotoma, with relative augmentation with smaller targets (Figure 4). The central target only presented an island of peripheral vision, localized on the lower hemifield. The computerized visual field exam, central 30-2 threshold test revealed the following: Right eye: average sensitivity of visual field normal for this age bracket. Left eye: $(\mathrm{MD}=-1.49 \mathrm{~dB})>$ blind spot with relative growth. CPSD $=2.46 \mathrm{~dB}, \mathrm{P}<10 \%$, indicating there is a localized defect which occurs in less than $10 \%$ of the normal population. The collaboration of the patient was reasonably good. Variations in answers in 10 standard sites studied were normal $(\mathrm{SF}=1.91 \mathrm{~dB})$. After 3 years of follow-up, there was no improvement of the patient's visual acuity.

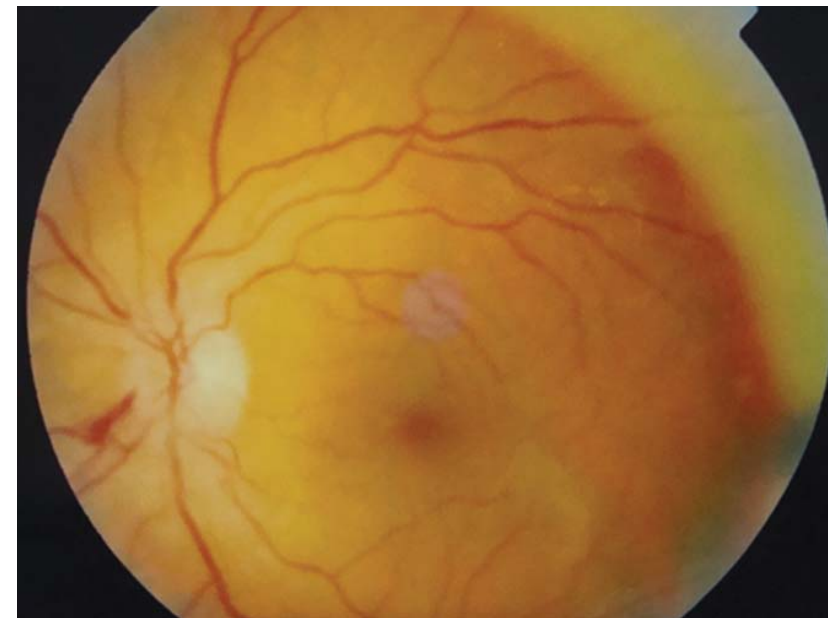

FIGURE 1: Retinography of the left eye showing blurring of the optic disc peripheral region, discrete disc paleness and dilation of disc capillaries, without retina detachment or breakages

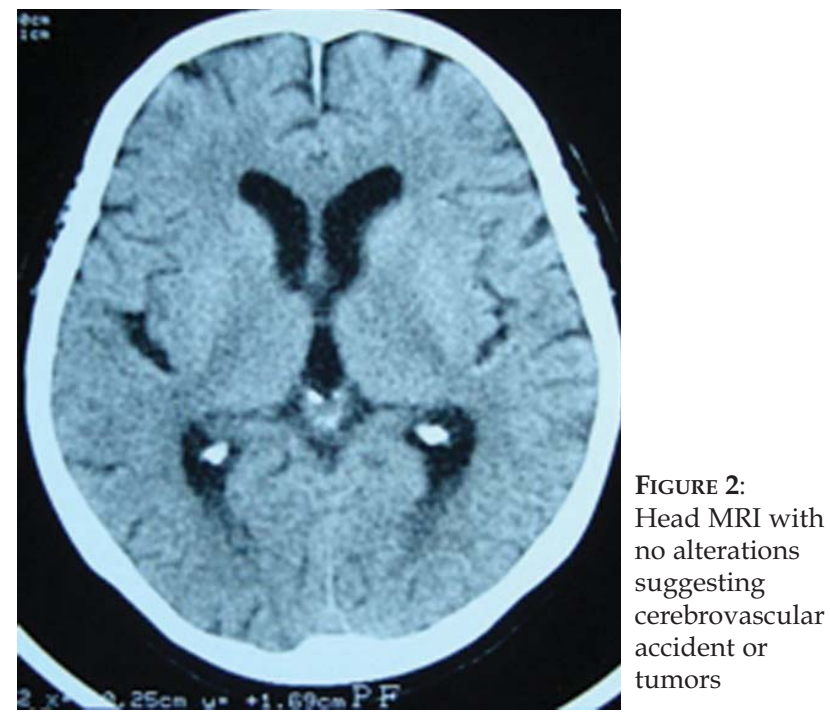




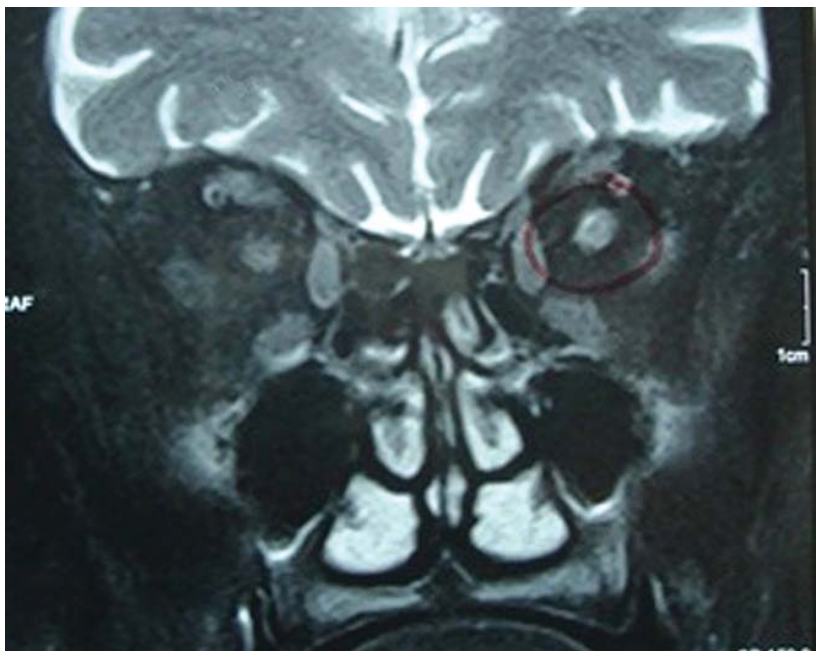

FIGURE 3: MRI - head coronal section, showing the left optic nerve (marked with purple circle) with hypersignal in comparison with the right optic nerve in $\mathrm{T} 2$

\section{DISCUSSION}

The biological agents are first-line drugs, and can be considered as the first therapeutic option in selected cases, especially for patients with severe psoriatic arthritis. ${ }^{3,45}$ Due to its efficacy in psoriasis treatment, they cause great impact on the quality of life of patients, promoting not only physical improvement but also psychosocial well-being. ${ }^{1,3,6}$ There is, however, and it must be remembered, the possibility of severe adverse effects. The majority of patients with optic neuritis, with partial or no improvement, were in older age groups. ${ }^{7,9}$ Pulse therapy with $1 \mathrm{~g}$ of methylprednisolone for 3 days is always indicated for optic neuritis and can be associated with corticotherapy with $1 \mathrm{mg} / \mathrm{kg} /$ day of oral prednisone. ${ }^{7.8}$ However, monotherapy with oral corticoids should be avoided, for it does not positively affect the recovery speed and

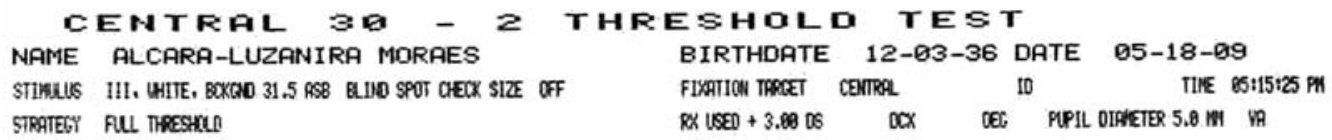


is associated with a higher recurrence rate..$^{10}$ The riskbenefit evaluation of biologics use is mandatory. It is the first case of optic neuritis caused by immunobiologics in a patient with psoriasis vulgaris, as the other cases reported were of patients with psoriatic arthritis. This is also the first case of optic neuritis associated with the use of infliximab prescribed for psoriasis, since in the other cases the drugs used were etanercept and adalimumab. ${ }^{7}$

Two points should be emphasized: the first is the fact that the referred patient is in an older group, over 60 years of age, than the other patients reported. The second is the progression of the disease. Our patient had loss of visual acuity with no recovery after 3 years of follow-up, while the younger patients had a higher rate of recovery.

\section{REFERENCES}

1. Consenso Brasileiro de Psoríase 2009. Rio de Janeiro: Sociedade Brasileira de Dermatologia; 2009. $115 \mathrm{p}$.

2. Griffiths CEM, Barker JNWN. Psoriasis. In: Burns T, Breathnach S, Cox N, Griffiths C, editors. Rook's Textbook of Dermatology. 8th. ed. Oxford: Wiley Blackwell; 2010. p. 20.1-60.

3. Duarte AA, Chehin FB. Moderate to severe psoriasis treated with infliximab - 53 patients: patients profile, efficacy and adverse effects. An Bras Dermatol. 2011;:86:257-63.

4. Torres T, Velho GC, Sanches M, Selores M. Psoriasis in the era of biologics. Acta Med Port. 2010;23:493-8.

5. Loyola AJC, Castro LCM, Chaibub SCW, Ximenes AC. Infliximab in treatment of severe psoriatic arthritis. An Bras Dermatol. 2005;80:535-7.

6. Diamantino F, Ferreira A. Future perspectives in the treatment of psoriasis: news in biological therapies. Acta Med Port. 2011;24:997-1004.

7. Tristano AG. Neurological adverse events associated with anti-tumor necrosis factor alpha treatment. J Neurol. 2010;257:1421-31.

8. Chan JW, Castellanos A. Infliximab and anterior optic neuropathy: case report and review of the literature. Graefes Arch Clin Exp Ophthalmol. 2010;248:283-7.

9. Simsek I, Erdem H, Pay S, Sobaci G, Dinc A. Optic neuritis occurring with anti-tumor necrosis factor $\alpha$ therapy. Ann Rheum Dis. 2007:66:1255-8.

10. Kanski JJ. Neuroftalmologia. In: Kanski JJ. Oftalmologia Clínica. 6 ed. Elsevier; 2008. p. $785-93$

MAILING ADDRESS:

Luiz Gustavo Martins da Silva

Avenida Antônio Borges de Queiroz, 162 - Centro

14730-000 - Monte Azul Paulista - SP

Brazil

E-mail: luizgustavodermatologia@gmail.com

How to cite this article: Martins da Silva LG, Sasso LS, Nelli CJ, Bernardes Filho F, Morgado de Abreu MAM. Optic neuritis due to immunobiologics: first Brazilian case report. An Bras Dermatol. 2013;88(6 Suppl 1):S161-5. 